\title{
Mortality in motorcycle accidents in Alagoas (2001-2015): temporal and spatial modeling before and after the "lei seca"
}

(iD) Carlos Dornels Freire de Souza ${ }^{1}$

(iD) João Paulo Silva de Paiva' (iD) Thiago Cavalcanti Leal' (D) Leonardo Feitosa da Silva ${ }^{1}$

iD Michael Ferreira Machado ${ }^{1}$

Maria Deysiane Porto de Araújo'

1. Núcleo de Estudos em Medicina Social e Preventiva (Nemsp), Departamento de Medicina, Universidade Federal de Alagoas, Arapiraca, AL, Brasil.

\section{SUMMARY}

OBJECTIVE: To analyze the epidemiological profile and the Spatio-temporal distribution of mortality in motorcycle accidents in Alagoas before (2001-2007) and after the "Lei seca" (2008-2015).

METHODS: This is a mixed ecologic study. All deaths in the state with the codes V20-V29 (ICD-10) as the basic cause were included in the study. Sociodemographic variables and mortality rates per sex were analyzed. For the temporal analysis, the inflection point regression model was used. For spatial analysis, the rates were smoothed by the Local Empirical Bayesian Model and, subsequently, the Global and Local Moran statistic was used to identify the spatial clusters of risk.

RESULTS: There were 1458 deaths caused by motorcycle accidents in the period studied; the following characteristics about the victims stand out: male (91.29\%), economically active age (82.93\%), and brown race (78.12\%). In the male population, there was a growth trend between 2001 and 2007 (19.0\%, $p<0.001)$, and a decline from 2008 (-11.2\%, $p<0.001)$. Spatial modeling showed that the areas with the highest risk of mortality are located in the agreste and sertão of the state $(p=0.01)$.

CONCLUSION: Mortality in motorcycle accidents is an important public health problem in Alagoas, with an emphasis on male mortality and geographic concentration within the state.

KEYWORDS: Accidents, Traffic. Ecological Studies. Mortality Registries.

\section{INTRODUCTION}

Over the past decades, traffic-related deaths and injuries have become an important global public health problem. In 2016 alone, 1.35 million people died worldwide due to traffic accidents, and the mortality rate is three times higher in low-income countries'.

In that same year, 37,345 deaths were reported due to traffic accidents in Brasil, with a rate of
18.1/100,000 inhabitants. Of these, $32 \%$ involved twoor three-wheel vehicles'. It is estimated that the risk of a fatal outcome in a motorcycle accident is 20 times higher than in car accidents ${ }^{2}$.

In 2008, in an attempt to reduce the number of traffic accidents, Law no. 11,705, popularly known as "Lei Seca", was enacted. Assessing the impact of

DATE OF SUBMISSION: 14-May-2019

DATE OF ACCEPTANCE: 30-Jun-2019

CORRESPONDING AUTHOR: Carlos Dornels Freire de Souza

Departamento de Medicina da Universidade Federal de Alagoas

Avenida Manoel Severino Barbosa, s/n - Bairro Bom Sucesso, Arapiraca, AL, Brasil - CEP 57309-005

Tel: 0879 9622-0698

E-mail: carlos.freire@arapiraca.ufal.br 
the legislation on the temporal and spatial pattern of traffic mortality is imperative for public health and safety ${ }^{3.4}$, in view of the magnitude of the problem and the need to understand the phenomenon in different geographical regions of the country and identify priority areas for intervention ${ }^{4}$.

Considering alcohol as the main risk factor for traffic mortality and the motorcyclist population as the most vulnerable, this study aimed to analyze the epidemiological profile and the Spatio-temporal distribution of mortality in motorcycle accidents in Alagoas before (2001-2007) and after the Lei Seca (2008-2015).

\section{METHODS}

This is a mixed ecologic study. This work was carried out in Alagoas, considering the period 2001-2015. The temporal series was subdivided into two, and the temporal milestone adopted was the year 2008, when the law entered into force. The state comprises 102 municipalities and a population of over 3 million inhabitants; it is the most densely populated area in the Northeast Region (112.13 inhabitants $\left./ \mathrm{km}^{2}\right)^{5}$.

We included all deaths due to transport accidents involving motorcycles and tricycles (driver/passenger), considering ICD-10, codes V2O-V29: V2O - Motorcycle rider injured in collision with pedestrian or animal; V21 - Motorcycle rider injured in collision with pedal cycle; V22 - Motorcycle rider injured in collision with two- or three-wheeled motor vehicle; V23 - Motorcycle rider injured in collision with car, pick-up truck or van; V24 - Motorcycle rider injured in collision with heavy transport vehicle or bus; V25 - Motorcycle rider injured in collision with railway train or railway vehicle; V26 Motorcycle rider injured in collision with other nonmotor vehicle; V27 - Motorcycle rider injured in collision with fixed or stationary object; V28 - Motorcycle rider injured in noncollision transport accident V29 - Motorcycle rider injured in other and unspecified transport accidents - NE. These data were obtained from the Mortality Information System (SIM) from the Datasus platform (http://datasus.saude.gov.br/).

Sociodemographic variables were collected in order to characterize the population studied: sex, age, race/color, formal education, marital status, place of death, and the ICD category. These variables were subjected to descriptive analysis. Then, the mortality rates in the general population and according to sex were calculated.

For the temporal analysis, we used the joinpoint regression model ${ }^{6}$. The trends were classified as stationary, ascending, or descending, and the Annual Percentage change (APC) and the Average Annual Percent Change (AAPC) were calculated. We adopted a significance of $5 \%$ and a confidence interval of $95 \%$.

Then, spatial analysis was conducted. Initially, we applied the local empirical Bayes model to the mortality rates to give greater stability to the data. After that, the spatial dependence of the indicators was evaluated using the statistic of the global Moran's statistic and the pseudo-significance test. Once global spatial dependency was observed, we applied the Local Index of Spatial Association - Lisa. From the Lisa, each municipality was placed in one quadrant of the Moran scatter plot: Q1 - High/high (positive values and positive means), Q2 - low/low (negative values and negative means), Q3 - high/low values (positive values and negative means), and Q4 - low/High (negative values and positive means). Based on the results obtained, the thematic maps were built to identify spatial clusters of higher risk of deaths ${ }^{7}$. For the analyses, we used the Terra View 4.2.2, QGis 2.14.11, and Joinpoint Regression Program 4.5.0.1 software.

Since the study used secondary data from information systems of public domain, it was waived approval by the Research Ethics Committee.

\section{RESULTS}

Between 2001 and 2015, 1,458 deaths were recorded due to motorcycle accidents in the state of Alagoas, 1,331 (91.29\%) of the victims were males, $39.09 \%(n=570)$ aged between 20 and 29 years, and $78.12 \%(\mathrm{n}=1139)$ of mixed race. There was a predominance of deaths in hospital units $(50.34 \%$; $n=734)$, followed by on public roads $(44.58 \% ; \mathrm{n}=650)$ (Table 1); $50.14 \%(\mathrm{n}=731)$ of deaths resulted from transport accidents without collision (Table 1).

The mortality rate in the period was 3.06 deaths/100 thousand inhabitants $(5.69 / 100,000$ for men, and 0.52/100,000 for women). In the period prior to the Lei Seca (2001-2007), there was a statistically significant growth of overall mortality (APC 18.9\%; $\mathrm{p}<0.001$ ) and among males (APC 19.0\%; $\mathrm{p}<0.001)$. In the period after the law went into force (2008-2015), there was a trend reversal, with a decline of $-11.3 \%$ $(p<0.001)$ in the overall mortality and $-11.2 \%(p<0.001)$ among men. Among women, the behavior was constant in both periods (Table 2).

The spatial distribution showed expansion of 
TABLE 1. SOCIODEMOGRAPHIC CHARACTERISTICS OF DEATHS FROM MOTORCYCLE TRAFFIC ACCIDENTS. ALAGOAS, BRASIL, 2001-2015 ( $N=1,458)$.

\begin{tabular}{|c|c|c|c|c|c|c|}
\hline \multirow[t]{2}{*}{ Variable } & \multicolumn{2}{|c|}{\begin{tabular}{|l|} 
Male \\
$1,331(91.29 \%)$
\end{tabular}} & \multicolumn{2}{|c|}{$\begin{array}{l}\text { Female } \\
127(8.71 \%)\end{array}$} & \multicolumn{2}{|c|}{$\begin{array}{l}\text { Total } \\
1,458(100.0 \%)\end{array}$} \\
\hline & $n$ & $\%$ & $n$ & $\%$ & $n$ & $\%$ \\
\hline \multicolumn{7}{|l|}{ Age range } \\
\hline$<10$ years & 4 & 0.31 & 1 & 0.79 & 5 & 0.35 \\
\hline 10 a 14 & 14 & 1.05 & 4 & 3.15 & 18 & 1.23 \\
\hline 15 a 19 & 140 & 10.52 & 20 & 15.75 & 160 & 10.97 \\
\hline 20 a 29 & 523 & 39.29 & 47 & 37.01 & 570 & 39.09 \\
\hline 30 a 39 & 319 & 23.97 & 28 & 22.05 & 347 & 23.80 \\
\hline 40 a 49 & 196 & 14.73 & 11 & 8.66 & 207 & 14.20 \\
\hline 50 a 59 & 78 & 5.86 & 7 & 5.51 & 85 & 5.84 \\
\hline 60 or more & 57 & 4.29 & 9 & 7.09 & 66 & 4.52 \\
\hline \multicolumn{7}{|l|}{ Race/color } \\
\hline White & 96 & 7.21 & 17 & 13.39 & 113 & 7.75 \\
\hline Black & 16 & 1.20 & 2 & 1.57 & 18 & 1.23 \\
\hline Yellow & 2 & 0.15 & 1 & 0.79 & 3 & 0.21 \\
\hline Brown & 1,050 & 78.89 & 89 & 70.08 & 1,139 & 78.12 \\
\hline Indigenous & 1 & 0.08 & 0 & 0.00 & 1 & 0.07 \\
\hline Ignored & 166 & 12.47 & 18 & 14.17 & 184 & 12.62 \\
\hline \multicolumn{7}{|l|}{ Years of formal education } \\
\hline None & 19 & 1.43 & 2 & 1.57 & 21 & 1.44 \\
\hline 1 to 3 years & 48 & 3.61 & 2 & 1.57 & 50 & 3.43 \\
\hline 4 to 7 years & 182 & 13.67 & 16 & 12.60 & 198 & 13.58 \\
\hline 8 to 11 years & 70 & 5.26 & 9 & 7.09 & 79 & 5.42 \\
\hline 12 or more & 7 & 0.53 & 0 & 0.00 & 7 & 0.48 \\
\hline Ignored & 1,005 & 75.51 & 98 & 77.17 & 1103 & 75.65 \\
\hline \multicolumn{7}{|l|}{ Site } \\
\hline Hospital & 667 & 50.11 & 67 & 52.76 & 734 & 50.34 \\
\hline Other health establishments & 4 & 0.30 & 0 & 0.00 & 4 & 0.27 \\
\hline Home & 15 & 1.13 & 1 & 0.79 & 16 & 1.10 \\
\hline Public Road & 594 & 44.63 & 56 & 44.09 & 650 & 44.58 \\
\hline Others & 51 & 3.83 & 3 & 2.36 & 54 & 3.71 \\
\hline \multicolumn{7}{|l|}{ ICD-10 Category } \\
\hline V2O & 10 & 0.75 & 0 & 0.00 & 10 & 0.69 \\
\hline V21' & - & - & - & - & - & - \\
\hline V22 & 18 & 1.35 & 1 & 0.79 & 19 & 1.30 \\
\hline V23 & 82 & 6.16 & 14 & 11.02 & 96 & 6.58 \\
\hline V24 & 30 & 2.25 & 4 & 3.15 & 34 & 2.33 \\
\hline V25' & - & - & - & - & - & - \\
\hline V26 & 11 & 0.83 & 0 & 0.00 & 11 & 0.75 \\
\hline V27 & 15 & 1.13 & 1 & 0.79 & 16 & 1.10 \\
\hline V28 & 674 & 50.64 & 57 & 44.88 & 731 & 50.14 \\
\hline V29 & 491 & 36.89 & 50 & 39.37 & 541 & 37.11 \\
\hline
\end{tabular}

Legend: V2O - Motorcycle rider injured in collision with pedestrian or animal; V21 - Motorcycle rider injured in collision with pedal cycle; V22 - Motorcycle rider injured in collision with two- or three-wheeled motor vehicle; V23 - Motorcycle rider injured in collision with car, pick-up truck or van; V24 - Motorcycle rider injured in collision with heavy transport vehicle or bus; V25 - Motorcycle rider injured in collision with railway train or railway vehicle; V26 - Motorcycle rider injured in collision with other nonmotor vehicle; V27 - Motorcycle rider injured in collision with fixed or stationary object; V28 - Motorcycle rider injured in noncollision transport accident V29 - Motorcycle rider injured in other and with fixed or stationary object; $\mathrm{V}$ unsecified transport accidents - NE. * No records of death in these categories.
un 
TABLE 2. TEMPORAL EVOLUTION AND MORTALITY RATE TREND IN MOTORCYCLE TRAFFIC ACCIDENTS (PER 100,000 INHABITANTS), OVERALL AND ACCORDING TO SEX. ALAGOAS, BRASIL, 2001-2015 ( $N=1,458)$.

\begin{tabular}{|c|c|c|c|c|c|c|}
\hline \multicolumn{7}{|c|}{ (a) Mortality rate in motorcycle accidents } \\
\hline \multirow[t]{2}{*}{ Year } & \multicolumn{2}{|c|}{ Overall mortality } & \multicolumn{2}{|c|}{ Male mortality } & \multicolumn{2}{|c|}{ Female mortality } \\
\hline & No. deaths & Rate $/ 100,000$ & No. deaths & Rate/100,000 & No. deaths & Rate/100,000 \\
\hline 2001 & 33 & 1.12 & 29 & 2.00 & 4 & 0.27 \\
\hline 2002 & 60 & 2.02 & 59 & 4.02 & 1 & 0.07 \\
\hline 2003 & 70 & 2.32 & 64 & 4.31 & 6 & 0.39 \\
\hline 2004 & 84 & 2.75 & 71 & 4.73 & 13 & 0.84 \\
\hline 2005 & 103 & 3.34 & 94 & 6.19 & 9 & 0.57 \\
\hline 2006 & 111 & 3.56 & 104 & 6.79 & 7 & 0.44 \\
\hline 2007 & 129 & 4.10 & 118 & 7.63 & 11 & 0.69 \\
\hline 2008 & 116 & 3.65 & 107 & 6.86 & 9 & 0.56 \\
\hline 2009 & 118 & 3.68 & 109 & 6.94 & 9 & 0.55 \\
\hline 2010 & 124 & 3.84 & 115 & 7.27 & 9 & 0.55 \\
\hline 2011 & 118 & 3.62 & 108 & 6.78 & 10 & 0.60 \\
\hline 2012 & 129 & 3.93 & 116 & 7.24 & 13 & 0.77 \\
\hline 2013 & 142 & 4.30 & 126 & 7.83 & 16 & 0.95 \\
\hline 2014 & 58 & 1.75 & 53 & 3.28 & 5 & 0.29 \\
\hline 2015 & 63 & 1.89 & 58 & 3.57 & 5 & 0.29 \\
\hline $2001-2015$ & 1,458 & 3.06 & 1,331 & 5.69 & 127 & 0.52 \\
\hline \multicolumn{7}{|c|}{ (b) Joinpoint Regression Model } \\
\hline Period & \multicolumn{2}{|c|}{$\begin{array}{l}\text { APC (Cl 95\%) } \\
\text { p-value }\end{array}$} & \multicolumn{2}{|c|}{$\begin{array}{l}\text { APC (Cl 95\%) } \\
\text { p-value }\end{array}$} & \multicolumn{2}{|c|}{$\begin{array}{l}\text { APC (CI 95\%) } \\
\text { P-value }\end{array}$} \\
\hline $2001-2007^{a}$ & \multicolumn{2}{|c|}{$\begin{array}{l}18.9(12.0 \text { to } 26.3) \\
p<0.001^{*}\end{array}$} & \multicolumn{2}{|c|}{$\begin{array}{l}19.0(9.9 \text { to } 28.9) \\
p<0.001^{*}\end{array}$} & \multicolumn{2}{|c|}{$\begin{array}{l}4.9(-3.3 \text { to } 13.9) \\
p=0.2\end{array}$} \\
\hline $2008-2015^{b}$ & \multicolumn{2}{|c|}{$\begin{array}{l}-11.3(-18.5 \text { to }-3.6) \\
p<0.001^{*}\end{array}$} & \multicolumn{2}{|c|}{$\begin{array}{l}-11.2(-20.5 \text { to }-0.7) \\
p<0.001^{*}\end{array}$} & \multicolumn{2}{|c|}{$\begin{array}{l}4.9(-3.3 \text { to } 13.9) \\
p=0.2\end{array}$} \\
\hline
\end{tabular}

Legend: * Statistical significance; APC: Annual Percent Change; AAPC: Average Annual Percent Change; Cl 95\%: Confidence interval of 95\%; a Period before the Lei Seca went into force in Brasil; $b$ Period the Lei Seca went into force in Brasil.

mortality over the time series, as well as a spatial dependency $(\mathrm{p}=0.01)$. Before the Lei Seca, the greatest overall rates corrected were found in Coité do Noia $(7.8 / 100,000)$, Craíbas (7.22/100,000), and Arapiraca (6.93/100,000). These municipalities also occupied the top three positions in the ranking of male mortality $(14.32 / 100,000$, $13.8 / 100,000$, and $6.93 / 100,000$, respectively). In the female population, the municipalities of Coité do Noia $(1.44 / 100,000)$, Feira Grande (1.56/100,000), and São Sebastião $(1.51 / 100,000)$ stood out (Figure 1).

In the post-enforcement period, the municipalities of Taquarana $(7.43 / 100,000)$, Arapiraca $(6.91 / 100,000)$, and Cacimbinhas $(6.86 / 100,000)$ stood out for the general mortality; Taquarana (14.13/100,000), Cacimbinhas (13.59/100,000), and Porto Real do Colégio $(12.95 / 100,000)$ for male mortality; and Pão de Açúcar $(2.11 / 100,000)$, São José da Tapera $(2.11 / 100,000)$, and Monteirópolis $(1,82 / 100,000)$ for female mortality (Figure 1).
The expansion of mortality was also observed in the Moran Map. For the overall mortality, the number of municipalities located in quadrant 1(Q1) of the Moran scatter plot went from 20 (19.60\%), before the Lei Seca, to $33(32.35 \%)$ in the period after it went into force. In the male population, the growth was similar, from 21 (20.58\%) to 32 (31.37\%). In both cases, the municipalities were concentrated in the central region of the state (agreste of Alagoas and transition with the sertão). In the female population, the same number of municipalities was observed ( $\mathrm{n}=19 ; 18.62 \%)$ in both periods; however, there was a change in the spatial pattern, with an expansion of mortality to the sertão of the state.

\section{DISCUSSION}

The male mortality rate 10.9 times higher than that of females observed in Alagoas corroborates the national and international literature ${ }^{\mathbf{8 1}}$. Of the 38,000 
accidents with fatal victims recorded in Brasil in 2015, $82 \%$ of deaths were of men ${ }^{1}$. Various aspects can justify this context, highlighting, initially, the higher consumption of motorcycles by the male population ${ }^{9}$. Approximately $85 \%$ of purchases of such vehicles in the country are by men, and $83 \%$ of purchasers are less than 40 years old ${ }^{10}$.

In association with the consumption profile, the male population has a higher prevalence of risk behaviors, such as the consumption of alcohol ${ }^{11}$, excess speeding $^{8}$, no use of personal protective equipment ${ }^{11}$, driving without a license ${ }^{12}$, and lack of knowledge of traffic legislation ${ }^{12}$. These factors explain why the risk of motorcycle accidents is substantially higher in this group ${ }^{10}$.

The prevalence of deaths in the mixed-race group can be explained by the Brazilian demographic characteristic since $43.1 \%$ of the population belongs to this race/ethnicity ${ }^{13}$. In addition, a study by Malta et al. ${ }^{11}$ pointed out that, in the Brazilian population, mixedrace individuals wear a helmet less often than white individuals, both as the driver ( 82.1 and $87.9 \%$, respectively) and as a passenger (78.1 and $86.4 \%$, respectively). This points to the existence of sociocultural factors that determine the use of personal protective equipment.

In addition to all of these factors described, there has also been an increase in the number of motorcycles. In 2001, the number of two-wheeled vehicles in Alagoas was 33,209; in 2005 , into was 58,579 (an increase of $76.3 \%)^{14}$. The epidemiological results of this entire context of vulnerabilities justify the upward trend in mortality, observed in our study between 2001 and 2007, with a percentage growth rate of $18.9 \%$ in the general population and $19.0 \%$ among males, as well as the geographic expansion of occurrences.

In addition to the proximal social determinants, it is pertinent to highlight those of a more distant sphere, i.e., the socioeconomic changes of the first decade of the 21st century, such as improved purchasing power, mainly in the North and Northeast regions of the country ${ }^{15}$, the percentage of the population that left the poverty range $\mathrm{e}^{16}$, and the lower cost of motorcycles when compared to four-wheeled vehicles ${ }^{15}$. In addition, motorcycles assumed an important role in the dynamics of the Brazilian economy, since it has become an opportunity to scape unemployment ${ }^{17}$.

The approval of the Brazilian Traffic Code, in

\section{FIGURE 1}

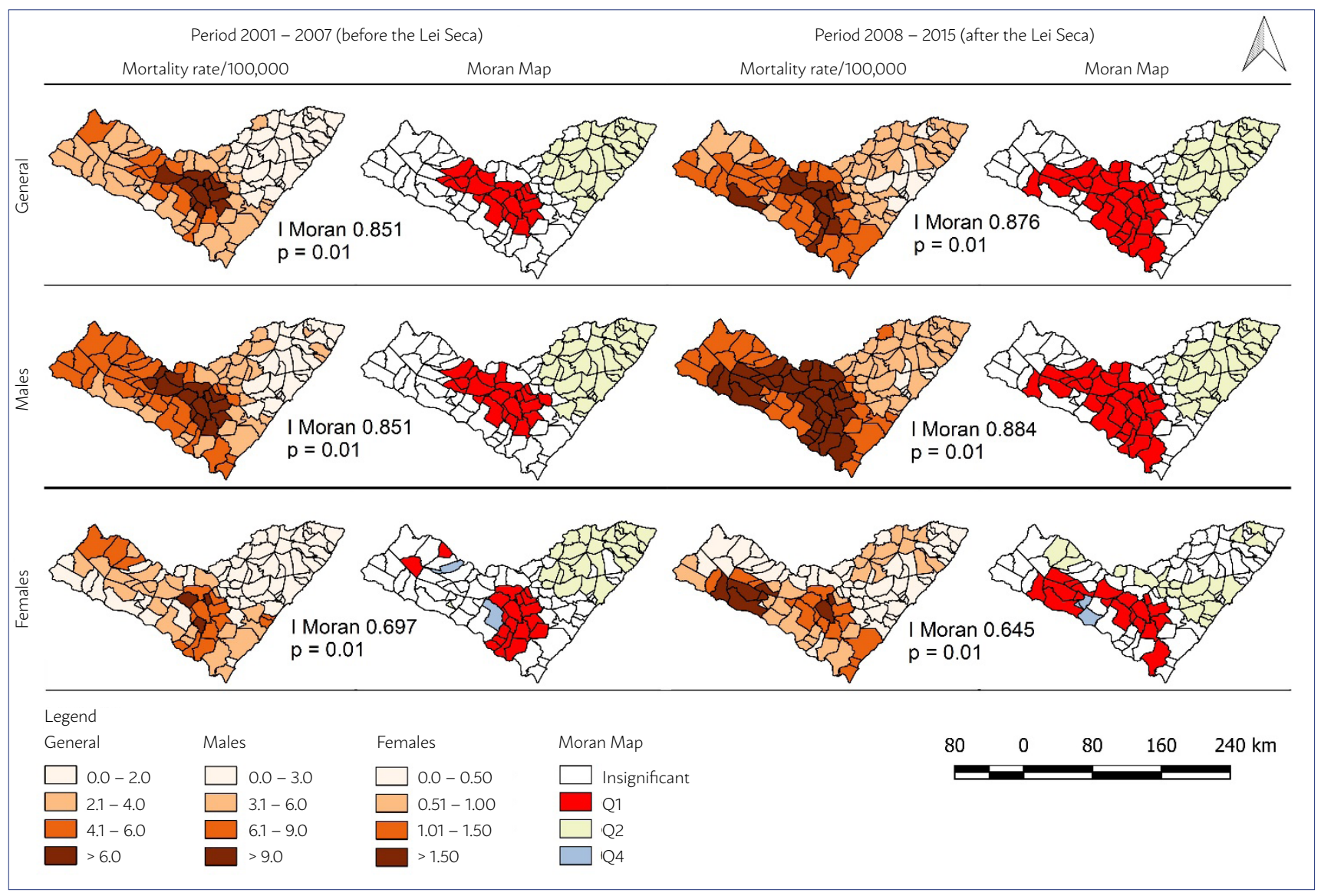


$1997^{18}$, did not have the expected effect; there was a reduction only in the first years when the number of deaths from traffic accidents dropped from 35,000 (1997) to $29,000(2000)^{19.20}$. Due to the need for new mechanisms capable of making the Brazilian traffic safer, the Lei Seca (Law No. 11.705/2008) was created in an attempt to prevent drinking and driving ${ }^{21}$. A national study showed a less pronounced growth of mortality after it went into force ${ }^{20}$, resembling the temporal pattern observed in Alagoas from 2008. In 2013, the decision 432 of the National Traffic Council lowered the levels of alcohol accepted in the blood-alcohol content test and raised the value of the fines for offenders ${ }^{22}$, making the law even more severe.

It is also necessary to discuss the geographical distribution of these deaths and raise potential local factors associated with patterns of mortality. In this study, the areas of greatest risk were concentrated in the agreste and sertão in municipalities with a smaller population. Similar results were found in Pernambuco, where the highest mortality rates were in the interior of the state ${ }^{23}$. In addition, national research pointed to municipalities with up to 20,000 inhabitants and from 20,000 to 100,000 at higher risk of mortality in comparison to larger municipalities ${ }^{23}$. In Alagoas, only Maceió and Arapiraca have a population of over 200,000 inhabitants. In these municipalities, the determinant factors previously discussed are heightened by the absence of a state supervisory power ${ }^{23}$.

\section{CONCLUSION}

The study showed consistent evidence that mortality from motorcycle traffic accidents is an important public health problem in the state of Alagoas, even after considering the positive impacts of the Lei Seca. We highlighted the male mortality and geographic expansion of deaths, which were concentrated on the interior of Alagoas (agreste and sertão regions).

\section{Conflicts of interest:}

None. No financial funding was received. This study was waived approval by the Research Ethics Committee.

\section{Contribution of the authors}

Carlos Dornels Freire de Souza; Leonardo Feitosa da Silva; Thiago Cavalcanti Leal; João Paulo Silva de Paiva: Participated in the development of the concept, planning of the study, data collection and analysis, discussion of the results, scientific writing, as well as in the review and approval of the final version of the work.

Michael Ferreira Machado; Maria Deysiane Porto de Araújo: Participated in the writing of the results, discussion, scientific writing, as well as in the review and approval of the final version of the work.

\section{RESUMO}

OBJETIVO: Analisar o perfil epidemiológico e a distribuição espaço-temporal da mortalidade em acidentes motociclísticos em Alagoas antes (2001-2007) e após a lei seca (2008-2015).

MÉTODOS: Estudo ecológico misto. Foram incluídos no estudo todos os óbitos ocorridos no estado que tiveram como causa básica os códigos V20-V29 (CID-10). Foram analisadas as variáveis sociodemográficas e as taxas de mortalidade calculadas segundo sexo. Para a análise temporal, empregou-se o modelo de regressão por pontos de inflexão. Para análise espacial, as taxas foram suavizadas pelo Modelo Bayesiano Empírico Local e, posteriormente, foi empregada a estatística de Moran Global e Local para a identificação dos aglomerados espaciais de risco.

RESULTADOS: Foram registrados 1.458 óbitos em acidentes motociclísticos no período estudado, destacando-se: sexo masculino (91,29\%), idade economicamente ativa (82,93\%) e raça parda (78,12\%). Na população masculina, verificou-se tendência de crescimento entre 2001 e 2007 (19,0\%; $p<0,001)$ e de declínio a partir de 2008 (-11,2\%; $p<0,001)$. A modelagem espacial mostrou que as áreas de maior risco de mortalidade estão situadas no agreste e sertão do estado $(p=0,01)$.

CONCLUSÃO: A mortalidade em acidentes motociclísticos é um importante problema de saúde pública em Alagoas, com destaque para a mortalidade masculina e concentração geográfica no interior do estado.

PALAVRAS-CHAVE: Acidentes de trânsito. Estudos ecológicos. Registros de mortalidade. 


\section{REFERENCES}

1. World Health Organization (WHO). Global status report on road safety 2015: supporting a decade of action. Geneva: World Health Organization; 2015

2. Beck LF, Dellinger AM, O'Neil ME. Motor vehicle crash injury rates by mode of travel, United States: using exposure-based methods to quantify differences. Am | Epidemiol. 2007;166(2):212-8.

3. Corgozinho MM, Montagner MA, Rodrigues MAC. Vulnerabilidade sobre duas rodas: tendência e perfil demográfico da mortalidade decorrente da violência no trânsito motociclístico no Brasil, 2004-2014. Cad Saúde Colet. 2018;26(1):92-9.

4. Morais Neto OL, Silva MMA, Lima CM, Malta DC, Silva Jr JB. Projeto Vida no Trânsito: avaliação das ações em cinco capitais brasileiras, 2011-2012. Epidemiol Serv Saude. 2013;22(3):373-82.

5. Instituto Brasileiro de Geografia e Estatística (IBGE). Censo Demográfico 2010. [citado em 2019 Jan 25]. Disponível em: <https://www.ibge.gov.br>.

6. Kim HJ, Fay MP, Feuer EJ, Midthune DN. Permutation tests for joinpoint regression with applications to cancer rates. Stat Med. 2000;19(3):335-51.

7. Santos SM, Souza WV. Introdução à estatística espacial para a saúde pública. Brasília: Ministério da Saúde; 2007.

8. Silva PLN, Santos AGP, Cruz PKR, Rocha JFD, Ferreira IR, Silva VF. Morbimortalidade de acidentes de trânsito envolvendo motocicletas: uma revisão de literatura. J Health Biol Sci. 2018;6(4):437-48.

9. Vasconcellos EA. Risco no trânsito, omissão e calamidade: impactos do incentivo à motocicleta no Brasil. São Paulo: Ed. do Autor; 2013.

10. Associação Brasileira dos Fabricantes de Ciclomotores, Motonetas, Bicicletas e Similares (Abraciclo). Anuário da Indústria Brasileira de Duas Rodas, 2012. [citado em 2019 Jan 25]. Disponível em: <http://www.abraciclo.com.br/ anuario-2012>.

11. Malta DC, Andrade SSCA, Gomes N, Silva MMA, Morais Neto OL, Reis $A A C$, et al. Lesões no trânsito e uso de equipamento de proteção na população brasileira, segundo estudo de base populacional. Ciênc Saúde Colet. 2016;21(1):399-409.
12. Barros FHV, Silva LO, Roseno MASG, Olinda AG, Souza JBR, Amaral JJF. Prevalência dos acidentes de motocicleta envolvendo os adolescentes de Quixadá. Id on Line Rev Mult Psic. 2018;12(42 supl 1):511-24.

13. Instituto Brasileiro de Geografia e Estatística (IBGE). Censo 2010. [citado em 2019 Jan 25]. Disponível em: https://censo2010.ibge.gov.br

14. Departamento Nacional de Trânsito (DENATRAN). Frota de Veículos 2019. [citado em 2019 Jan 25]. Disponível em: <https://www.denatran.gov.br/ estatistica/237-frota-veiculos>

15. Rocha GS, Schor N. Acidentes de motocicleta no município de Rio Branco: caracterização e tendências. Ciênc Saúde Colet. 2013;18(3):721-31.

16. Instituto de Pesquisa Econômica Aplicada (IPEA). Mobilidade urbana e posse de veículos: análise da PNAD. 2009. Brasília: IPEA; 2010.

17. Silva DW, Andrade SM, Soares DA, Soares DFPP, Mathias TAF. Perfil do trabalho e acidentes de trânsito entre motociclistas de entregas em dois municípios de médio porte do Estado do Paraná, Brasil. Cad Saúde Pública. 2008;24(11):2643-52.

18. Brasil (BR). Lei $n^{0} 9.503$, de 23 de setembro de 1997. Institui o Código de Trânsito Brasileiro. Diário Oficial da União 1997;24 set. [citado em 2019 fev 12]. Disponível em: http://www.planalto.gov.br/ccivil_03/LEIS/L9503.htm.

19. Vasconcellos EA. Road safety impacts of the motorcycle in Brazil. Int J Inj Contr Saf Promot. 2013;20(2):144-51.

20. Abreu DROM, Souza EM, Mathias TAF. Impacto do Código de Trânsito Brasileiro e da Lei Seca na mortalidade por acidentes de trânsito. Cad Saúde Pública. 2018;34(8):e00122117.

21. Brasil (BR). Lei $n^{0} 11.705$, de 19 de junho de 2008. Altera a Lei $n^{0} 9.503$, de 23 de setembro de 1997. Diário oficial da União 2008;20 jun.

22. Departamento Nacional de Trânsito (DENATRAN). Resolução nº 432/13. [citado em 2019 Fev 12]. Disponível em: https://www.denatran.gov.br/ download/Resolucoes/(resolu\%C3\%A7\%C3\%A30\%20432.2013c).pdf

23. Silva PHNV, Lima MLC, Moreira RS, Souza WV, Cabral APS. Estudo espacial da mortalidade por acidentes de motocicleta em Pernambuco. Rev Saúde Pública 2011;45(2):409-15 